\title{
Transcription Factor E2F4
}

National Cancer Institute

\section{Source}

National Cancer Institute. Transcription Factor E2F4. NCI Thesaurus. Code C125266.

Transcription factor E2F4 (413 aa, $\sim 44 \mathrm{kDa}$ ) is encoded by the human E2F4 gene. This protein plays a role in the modulation of tumor suppressor-dependent gene expression. 